\title{
STRATEGI PENGUATAN KEWIRAUSAHAAN UNTUK MENINGKATKAN KINERJA USAHA (Survey pada Wirausaha Fesyen di BTC dan PGS Surakarta)
}

\author{
Retno Susanti \\ Fakultas Ekonomi Universitas Slamet Riyadi Surakarta \\ e-mail: rtnos santi@yahoo.com \\ Suprihatmi SW \\ Fakultas Ekonomi Universitas Slamet Riyadi Surakarta \\ e-mail: Suprihatmi60@gmail.com
}

\begin{abstract}
The creative economy of the fashion business in BTC and PGS Surakarta is very important to be developed because it contributes to the regional economy. Constraints faced in running a business such as entrepreneurship orientation is low, so that the business performance is not optimal. One strategy to encourage the development of creative economy in the business of fashion in Surakarta is to increase creativity and market orientation, in order to obtain maximum business performance. This study aims to analyze the effect of entrepreneurship orientation on business performance moderated by creativity and market orientation. Sample of this study are 123 entrepreneurs of fashion in BYC and PGS Surakarta, using purposive sampling technique. Data analysis using regression analysis and Absolute Difference Test. The conclusion of hypothesis test result (1) entrepreneurship orientation have significant effect on business performance; (2) creativity can moderate the effect of entrepreneurship orientation on business performance; (3) market orientation can moderate the effect of entrepreneurship orientation on business performance

Keywords: entrepreneurship orientation, creativity, market orientation, business performance
\end{abstract}

\section{PENDAHULUAN}

Solo selain dikenal dengan kota wisata dan kota batik, memiliki iklim bisnis dan perdagangan yang sangat kompetitif. Hal ini dapat dicontohkan dengan dibangunnya pasar modern Beteng Trade Center (BTC) dan Pusat Grosir Solo (PGS). Untuk memenuhi kebutuhan fesyen, BTC dan PGS adalah pusat perbelanjaan yang banyak dikunjungi warga kota Solo maupun para wisatawan yang sedang berkunjung ke kota Solo.

Dalam kompetisi bisnis fesyen, kinerja wirausaha fesyen dapat diukur dari peningkatan penjualan, peningkatan laba dan peningkatan pelanggan. Seperti yang dinyatakan Mulato Santosa \& Muhammad Nasir (2014: 569) ukuran yang dapat digunakan untuk menilai kinerja usaha adalah pertumbuhan penjualan, peningkatan kentungan bersih, inovasi produk/layanan, variasi produk, pengabdosian teknologi baru, dan kepuasan konsumen (Mulato Santosa \& Muhammad Nasir, 2014: 569).

Satu hal yang turut menentukan kesuksesan berwirausaha adalah orientasi 
kewirausahaan. Liao dan Sohmen (2001) menyatakan orientasi kewirausahaan adalah karakteristik dan nilai dari wirausaha itu sendiri, seperti pantang menyerah, berani mengambil risiko, kecepatan, dan fleksibilitas. Orientasi kewirausahaan dapat diukur dari kemampuan inovasi, kemampuan mengambil risiko, dan sifat proaktif (Weerawerdeena, 2003:411).

Temuan empiris menunjukkan bahwa terdapat hubungan yang signifikan antara orientasi kewirausahaan yang ditetapkan dengan kinerja perusahaan (Gosselin, 2005). Hal ini didukung temuan Heny Welsa (2009); Rita Indah Mustikowati \& Irma Tysari (2014); Dwi Wahyu Pril Ranto (2016).

Namun beberapa temuan lain yang dilakukan Dimitratos et al. (2004); Lupkin \& Dess (2001); Zahra (1991) menunjukkan lemahnya hubungan orientasi kewirausahaan dengan kinerja perusahaan (dalam Mulato Santosa \& Muhammad Nasir, 2014: 567).

Kreativitas dianggap sebagai salah satu strategi penting untuk kesuksesan suatu usaha di masa depan (Weinzimmer, 2011). Keberhasilan kreativitas pada suatu perusahaan tidak hanya ditentukan dari melakukan sesuatu dengan cara yang berbeda, tapi ide harus sesuai, bermanfaat, dan dapat dipraktekan untuk mempengaruhi perkembangan suatu perusahaan (Louis Utama dan Jeremy Kristanto Nadi (2017).
Selain kreativitas, faktor yang turut mendukung peningkatan kinerja usaha adalah orientasi pasar. Slater \& Narver dalam Perengki Susanto (2012: 45) menyatakan, orientasi pasar memiliki hubungan yang kuat dengan kinerja perusahaan. Orientasi pasar adalah budaya bisnis untuk menghasilkan kinerja terbaik melalui komitmen atas penciptaan nilai superior bagi pelanggan. Untuk memberikan nilai pelanggan yang superior perusahaan yang berorientasi pasar tidak hanya berorientasi pelanggan saja tetapi juga berorientasi pesaing dan koordinasi antar fungsi.

Sejalan dengan uraian di atas, orientasi kewirausahaan bagi pengusaha fesyen amat penting dimiliki karena turut menentukan kinerja usaha. Sebagai wirausaha fesyen harus memiliki semangat untuk menciptakan inovasi usaha, mampu mengambil risiko, dan proaktif. Untuk mengoptimalkan kinerja usaha, harus didukung kreativitas dan orientasi pasar. Pemilik usaha fesyen di BTC dan PGS Surakarta harus terus berkreasi menciptakan ide-ide baru baik dalam cara pengambilan keputusan, promosi, proses produksi, dan juga berinovasi pada tempat jualnya sendiri sehingga dapat berkompetisi dengan pesaing-pesaing yang ada. Kreativitas dan orientasi pasar dapat digunakan sebagai strategi penguatan kewirausahaan untuk meningkatkan kinerja usaha. Kreativitas dan 
orientasi pasar diharapkan dapat memperkuat hubungan orientasi kewirausahaan dengan kinerja usaha pada wirausaha fesyen di BTC dan PGS Surakarta.

Luaran penelitian ini adalah artikel yang dipublikasikan pada JURNAL EKONOMI DAN KEWIRAUSAHAAN, Universitas Slamaet Riyadi Surakarta.

Berdasarkan latar belakang yang penulis kemukakan diatas, maka perumusan masalah dalam penelitian ini adalah sebagai berikut :

1. Apakah orientasi kewirausahaan berpengaruh signifikan terhadap kinerja usaha pada pengusaha fesyen di BTC dan PGS Surakarta?.

2. Apakah kreativitas memoderasi pengaruh orientasi kewirausahaan terhadap kinerja usaha pada pengusaha fesyen di BTC dan PGS Surakarta ?.

3. Apakah orientasi pasar memoderasi pengaruh orientasi kewirausahaan terhadap kinerja usaha pada pengusaha fesyen di BTC dan PGS Surakarta ?.

Berdasarkan pokok masalah yang telah diutarakan sebelumnya, maka tujuan dari penelitian ini adalah sebagai berikut :

1. Untuk menganalisis signifikansi pengaruh orientasi kewirausahaan terhadap kinerja usaha pada pengusaha fesyen di BTC dan PGS Surakarta.

2. Untuk menganalisis signifikansi pengaruh orientasi kewirausahaan terhadap kinerja usaha yang dimoderasi kreativitas pada pengusaha fesyen di BTC dan PGS Surakarta.

3. Untuk menganalisis signifikansi pengaruh orientasi kewirausahaan terhadap kinerja usaha yang dimoderasi orientasi pasar pada pengusaha fesyen di BTC dan PGS Surakarta.

Kontribusi penelitian adalah memberikan pemahaman teoritis, metodologis dan praktis tentang pengaruh orientasi kewirausahaan terhadap kinerja usaha yang dimoderasi kreativitas dan orientasi pasar. Penelitian ini dapat digunakan sebagai acuan bagi pengusaha fesyen di Surakarta bahwa kreativitas dan orientasi pasar dapat digunakan sebagai strategi penguatan kewirausahaan yang selanjutnya akan memberikan kontribusi pada peningkatan kinerja usaha.

\section{METODE PENELITIAN}

Jenis penelitian ini adalah penelitian survey dengan menggunakan pendekatan kuantitatif, di mana analisis data yang dilakukan dalam penelitian ini dengan melakukan perhitungan statistik. Populasi dalam penelitian ini seluruh pengusaha fesyen di Beteng Trade Center (BTC) dan Pusat Grosir Solo (PGS) Surakarta. Teknik pengambilan sampel yang digunakan adalah purposive sampling. Adapun kriteria sampel yang digunakan adalah para pengusaha di BTC dan 
PGS Surakarta yang memproduksi dan menjual produk fesyen, dan sudah beroperasi minimal lima tahun. Dari hasil perhitungan diperoleh jumlah sampel yang memenuhi kriteria sebanyak 123 responden.

Orientasi kewirausahaan adalah persepsi manajer atas kesediannya dalam melakukan keinovasian, keproaktifan, dan keberanian berisiko dalam menjalankan perusahaan. Orientasi kewirausahaan adalah kombinasi dari tiga dimensi: inovasi, keproaktifan dan kemampuan mengambil risiko (Mulato Santosa \& Muhammad Nasir, 2014: 569). Orientasi pasar merupakan perilaku untuk memberikan nilai superior kepada pelanggan, respon terhadap tindakan pesaing dan melakukan komunikasi secara internal. Berdasarkan definisi tersebut, maka orientasi pasar diukur oleh tiga indikator yaitu orientasi pelangan, orientasi pesaing dan koordinasi antar fungsi (Nerver dan Slater dalam Halim, 2011:475). Kreativitas adalah kemampuan pengusaha untuk dapat memikirkan, menghasilkan, dan mengembangkan ide-ide dan cara-cara baru yang dapat berguna untuk melihat masalah dan peluang sehingga dapat menghasilkan solusi yang kreatif. Aspek-aspek yang dijadikan penilaian kreativitas yaitu otonomi, percaya diri, bebas dari rasa takut gagal, berfikir dalam imajinasi, memperhitungkan resiko, gigih, kemampuan mengasah ide-ide baru, motivasi (Ernani Hadiyati, 2011). Kinerja usaha adalah persepsi manajer/pemilik perusahaan terhadap perkembangan kinerja perusahaan dibandingkan dengan pesaing. Variabel ini diukur dengan 6 indikator yaitu pertumbuhan penjualan, peningkatan kentungan bersih, inovasi produk/layanan, variasi produk, pengabdosian teknologi baru, dan kepuasan konsumen (Mulato Santosa \& Muhammad Nasir, 2014: 569).

Teknik pengumpulan data dalam penelitian ini kuesioner yang dikur dengan skala Likert 5 poin. Uji validitas dan relaibilitas instrumen digunakan untuk menguji kualitas. Uji Asumsi Klasik dilakukan melalui empat uji yaitu uji multikolinieritas, uji autokorelasi, uji heteroskedastisitas, dan uji normalitas. Teknik analisis data menggunakan analisis regresi sederhana dan uji selisih mutlak yang dinyatakan dengan persamaan sebagai berikut:

$\mathrm{Y}=\alpha+\beta 1 \mathrm{X} 1$

$\mathrm{Y}=\mathrm{a}+\mathrm{b}_{1} \mathrm{ZX}_{1}+\mathrm{b}_{2} \mathrm{ZX}_{2}+\mathrm{b}_{3} \mid \mathrm{ZX}_{1^{-}}$

$\mathrm{ZX}_{2} \mid+\mathrm{e}$

$\mathrm{Y}=\mathrm{a}+\mathrm{b}_{1} \mathrm{ZX}_{1}+\mathrm{b}_{2} \mathrm{ZX}_{3}+\mathrm{b}_{3} \mid \mathrm{ZX}_{1^{-}}$ $\mathrm{ZX}_{3} \mid+\mathrm{e}$

Keterangan :

Y: Kinerja usaha

$\mathrm{X} 1$ : Orientasi kewirausahaan

X2: Kreativitas

X3: Orientasi pasar

a: Konstanta

$b_{1} . . b_{3}$ : Koefisien regresi 
$\mathrm{ZX}_{1} \quad$ : $\quad$ Standardized orientasi

kewirausahaan

$\mathrm{ZX}_{3}$ : Standardized orientasi pasar

$\left|\mathrm{ZX}_{1}-\mathrm{ZX}_{2}\right|$ : Nilai Absolut $\mathrm{ZX}_{1}$ -

$\mathrm{ZX}_{2}$ (Moderasi 1)

$\left|\mathrm{ZX}_{1}-\mathrm{ZX}_{3}\right|$ : Nilai Absolut $\mathrm{ZX}_{1-}$ $\mathrm{ZX}_{3}$ (Moderasi 2)

e : error

Pengujian hipotesis dilakukan melalui uji $\mathrm{t}$ dengan menggunakan tingkat signifikansi 5\%. Uji F bertujuan untuk menguji ketepatan model. Uji koefisien determinasi bertujuan untuk mengetahui persentase sumbangan pengaruh variabel independen terhadap terhadap kinerja usaha.

\section{HASIL DAN PEMBAHASAN}

Karakteristik Demografi

Karakteristik demografi responden disajikan seperti tabel 1 berikut. Tabel 1: Analisis Karakteristik Demografi Responden

\begin{tabular}{|c|c|c|c|}
\hline Karakteristik & Keterangan & Jumlah (orang) & Persentase $(\%)$ \\
\hline \multirow[t]{3}{*}{ Jenis Kelamin } & Laki-laki & 52 & 42,28 \\
\hline & Perempuan & 71 & 57,72 \\
\hline & Total & 123 & 100,00 \\
\hline Tingkat & SD & 2 & 1,63 \\
\hline \multirow[t]{6}{*}{ Pendidikan } & SMP & 36 & 29,27 \\
\hline & SMA & 54 & 43,90 \\
\hline & Diploma (D1/D2/D3) & 23 & 18,70 \\
\hline & Sarjana (S1) & 8 & 6,50 \\
\hline & Sarjana (S2) & 0 & 0,00 \\
\hline & Total & 123 & 100,00 \\
\hline Tingkat & Pelajar/Mahasiswa & 7 & 7,29 \\
\hline \multirow{5}{*}{ Pekerjaan } & Pegawai Negeri & 15 & 15,63 \\
\hline & Pegawai Swasta & 24 & 25,00 \\
\hline & Wiraswasta & 38 & 39,58 \\
\hline & Pekerjaan lain & 12 & 12,50 \\
\hline & Total & 96 & 100,00 \\
\hline Status & Menikah & 87 & 70,73 \\
\hline \multirow[t]{3}{*}{ Perkawinan } & Belum Menikah & 7 & 5,69 \\
\hline & Duda/Janda & 29 & 23,58 \\
\hline & Total & 123 & 100,00 \\
\hline \multirow[t]{4}{*}{ Lama Usaha } & $6-10$ tahun & 3 & 2,44 \\
\hline & $11-15$ tahun & 67 & 54,47 \\
\hline & Lebih dari 15 tahun & 53 & 43,09 \\
\hline & Total & 123 & 100,00 \\
\hline Jumlah & $1-5$ orang & 12 & 9,76 \\
\hline Tenaga & $6-10$ orang & 36 & 29,27 \\
\hline \multirow[t]{2}{*}{ Kerja } & Lebih dari 10 orang & 75 & 60,98 \\
\hline & Total & 123 & 100,00 \\
\hline
\end{tabular}

Sumber : Data primer diolah, 2019

Hasil Uji Validitas dan Reliabilitas Instrumen
Hasil uji validitas melalui uji Korelasi Pearson menunjukkan 
bahwa semua butir pernyataan untuk variabel orientasi kewirausahaan, kreativitas, orientasi pasar, dan kinerja usaha semuanya valid, ditunjukkan dengan $p$ value $<0,05$.
Hasil uji validitas butir dengan program SPSS disajika seperti tabel berikut.

Tabel 2: Hasil Uji Validitas

\begin{tabular}{|c|c|c|c|c|c|c|}
\hline \multirow[b]{2}{*}{ Item } & \multicolumn{4}{|c|}{$p$ value } & \multirow[t]{2}{*}{$\alpha$} & \multirow[t]{2}{*}{ Keterangan } \\
\hline & $\begin{array}{c}\text { orientasi } \\
\text { kewirausahaan }\end{array}$ & kreativitas & $\begin{array}{c}\text { orientasi } \\
\text { pasar }\end{array}$ & $\begin{array}{c}\text { kinerja } \\
\text { usaha }\end{array}$ & & \\
\hline 1 & 0,000 & 0,000 & 0,000 & 0,000 & 0,05 & Valid \\
\hline 2 & 0,000 & 0,000 & 0,000 & 0,000 & 0,05 & Valid \\
\hline 3 & 0,000 & 0,000 & 0,000 & 0,000 & 0,05 & Valid \\
\hline 4 & 0,000 & 0,000 & 0,000 & 0,000 & 0,05 & Valid \\
\hline 5 & 0,000 & 0,000 & 0,000 & 0,000 & 0,05 & Valid \\
\hline 6 & 0,000 & 0,000 & 0,000 & 0,000 & 0,05 & Valid \\
\hline 7 & 0,000 & 0,000 & 0,000 & & 0,05 & Valid \\
\hline 8 & 0,000 & 0,000 & 0,000 & & 0,05 & Valid \\
\hline 9 & 0,000 & & 0,000 & & 0,05 & Valid \\
\hline
\end{tabular}

Sumber : Data primer diolah, 2019

Berdasarkan uji reliabilitas instrumen diperoleh hasil bahwa instrumen untuk variabel orientasi kewirausahaan, kreativitas, orientasi pasar, dan kinerja usaha dinyatakan reliabel karena masing-masing variabel menghasilkan Cronbach
Alpha > 0,60. Berdasarkan pengolahan data dengan program SPSS berikut ini disajikan hasil uji reliabilitas untuk instrumen orientasi kewirausahaan, kreativitas, orientasi pasar, dan kinerja usaha.

Tabel 3: Hasil Uji Reliabilitas Instrumen

\begin{tabular}{lccc}
\hline \multicolumn{1}{c}{ Variabel } & Cronbach Alpha & Kriteria uji & Keterangan \\
\hline Orientasi Kewirausahaan & 0,754 & 0,60 & Reliabel \\
Kreativitas & 0,745 & 0,60 & Reliabel \\
Orientasi Pasar & 0,742 & 0,60 & Reliabel \\
Kinerja Usaha & 0,755 & 0,60 & Reliabel \\
\hline
\end{tabular}

Sumber : Data primer diolah, 2019

\section{Hasil Uji Asumsi Klasik}

Berdasarkan pengolahan data dengan program SPSS berikut ini disajikan hasil uji asumsi klasik meliputi Uji multikolinieritas, uji heteroskedastisitas, uji autokorelasi, dan uji normalitas.

Tabel 4: Hasil Uji Asumsi Klasik

\begin{tabular}{lll}
\hline \multicolumn{1}{c}{ Uji Asumsi Klasik } & \multicolumn{1}{c}{ Hasil Uji } & \multicolumn{1}{c}{ Kesimpulan } \\
\hline Uji & Tolerance $(0,943 ; 0,115 ; 0,117)>0,1$ & Tidak ada \\
Multikolinieritas & VIF $(1,060 ; 8,722 ; 8,558)<10$ & Multikolinieritas \\
Uji & $p$ value $(0,095 ; 0,084 ; 0,268)>0,05$ & Tidak ada \\
Heteroskedastisitas & & Heteroskedastisitas \\
Uji Autokorelasi & $p$ value $(0,322)>0,05$ & Tidak ada Autokorelasi \\
Uji Normalitas & $p$ value $(0,284)>0,05$ & Residual normal \\
\hline
\end{tabular}

Sumber : Data primer diolah, 2018 
Hasil uji asumsi klasik menunjukkan

$$
\text { tidak }
$$

terjadi

masalah

heteroskedastisitas, tidak terjadi masalah autokorelasi, dan residual bahwa model penelitian ini tidak normal. terjadi masalah multikolinieritas,

\section{Pengujian Hipotesis}

Berdasarkan analisis regresi dan uji selisih mutlak diperoleh hasil seperti tabel berikut.

Tabel 5. Hasil Uji Hipotesis

Variabel dependen: Kinerja Usaha (Y)

\begin{tabular}{ccccccc}
\hline Model & $\begin{array}{c}\text { Variabel } \\
\text { Independen }\end{array}$ & Nilai t & Sig. & R & Adj. $\mathrm{R}^{2}$ & $\mathrm{~F}$ \\
\hline 1 & $\mathrm{X}_{1}$ & 4,056 & 0,000 & 0,346 & 0,112 & 0,000 \\
\hline 2 & $\left|\mathrm{ZX}_{1}-\mathrm{ZX}_{2}\right|$ & 5,572 & 0,000 & 0,569 & 0,307 & 0,000 \\
\hline 3 & $\left|\mathrm{ZX}_{1}-\mathrm{ZX}_{3}\right|$ & 4,262 & 0,000 & 0,539 & 0,272 & 0,000 \\
\hline
\end{tabular}

Sumber: Data primer diolah, 2019

1. Pengaruh orientasi kewirausahaan terhadap kinerja usaha

Uji pengaruh orientasi kewirausahaan terhadap kinerja usaha menghasilkan nilai $\mathrm{t}$ hitung sebesar 4,056 dengan $p$ value $(0,000)<0,05$ maka H1 diterima, berarti orientasi kewirausahaan berpengaruh signifikan terhadap kinerja usaha pada pengusaha fesyen di BTC dan PGS Surakarta. Dari hasil uji $\mathrm{F}$ diperoleh $p$ value 0,000 yang jauh lebih kecil dari 0,05 . Berarti model 1 dalam penelitian ini dinyatakan fit (tepat) dalam memprediksi pengaruh orientasi kewirausahaan terhadap kinerja usaha. Dari hasil perhitungan koefisien determinasi diperoleh nilai Adj. $\mathrm{R}^{2}$ sebesar 0,112 berarti sumbangan pengaruh orientasi kewirausahaan terhadap kinerja usaha adalah sebesar $11,2 \%$ sisanya sebesar $88,8 \%$ dijelaskan oleh variabel lain yang tidak diteliti. Tingkat keeratan hubungan antara orientasi kewirausahaan dengan kinerja usaha ditunjukkan dengan koefisien korelasi $\mathrm{R}$ sebesar 0,346 artinya hubungan antara orientasi kewirausahaan dengan kinerja usaha dikategorikan rendah.

2. Pengaruh orientasi kewirausahaan terhadap kinerja usaha yang dimoderasi kreativitas

Berdasarkan perhitungan uji selisih mutlak diperoleh hasil bahwa pengaruh orientasi kewirausahaan terhadap kinerja usaha yang dimoderasi kreativitas menghasilkan nilai $\mathrm{t}$ 
hitung sebesar 5,572 dengan $p$ value $(0,000)<0,05$ maka $\mathrm{H} 2$ diterima, berarti kreativitas memoderasi pengaruh orientasi kewirausahaan terhadap kinerja usaha pada pengusaha fesyen di BTC dan PGS Surakarta.. Dari hasil uji $\mathrm{F}$ diperoleh $p$ value sebesar 0,000 yang jauh lebih kecil dari 0,05. Berarti model 2 dalam penelitian ini dinyatakan fit dalam memprediksi pengaruh orientasi kewirausahaan terhadap kinerja usaha yang dimoderasi kreativitas.Dari hasil perhitungan uji koefisien determinasi diperoleh nilai Adj. $R^{2}$ sebesar 0,307 berarti sumbangan pengaruh orientasi kewirausahaan terhadap kinerja usaha yang dimoderasi kreativitas adalah sebesar 30,7\% sisanya sebesar $69,3 \%$ dijelaskan oleh variabel lain yang tidak diteliti. Tingkat

keeratan hubungan antara orientasi kewirausahaan, kreativitas, dan moderasi dengan kinerja usaha ditunjukkan dengan koefisien korelasi $\mathrm{R}$ sebesar 0,569, artinya hubungan antara orientasi kewirausahaan, kreativitas, dan moderasi dengan kinerja usaha dikategorikan cukup kuat (sedang).

3. Pengaruh orientasi kewirausahaan terhadap kinerja usaha yang dimoderasi orientasi kewirausahaan
Berdasarkan perhitungan uji selisih mutlak diperoleh hasil bahwa pengaruh orientasi kewirausahaan terhadap kinerja usaha yang dimoderasi orientasi pasar menghasilkan nilai thitung sebesar 4,262 dengan $p$ value sebesar 0,000 yang jauh lebih kecil dari 0,05 maka $\mathrm{H} 3$ diterima, berarti orientasi pasar memoderasi pengaruh orientasi kewirausahaan terhadap kinerja usaha pada pengusaha fesyen di BTC dan PGS Surakarta. Dari hasil uji $\mathrm{F}$ diperoleh $p$ value sebesar 0,000 yang jauh lebih kecil dari 0,05. Berarti model 3 dalam penelitian ini dinyatakan fit dalam memprediksi pengaruh orientasi kewirausahaan terhadap kinerja usaha yang dimoderasi orientasi pasar. Dari hasil perhitungan uji koefisien determinasi diperoleh nilai Adj. $R^{2}$ sebesar 0,272 berarti sumbangan pengaruh orientasi kewirausahaan terhadap kinerja usaha yang dimoderasi orientasi pasar adalah sebesar 27,2\% sisanya sebesar $72,8 \%$ dijelaskan oleh variabel lain yang tidak diteliti. Tingkat keeratan hubungan antara orientasi kewirausahaan, orientasi pasar, dan moderasi dengan kinerja usaha ditunjukkan dengan koefisien korelasi $\mathrm{R}$ sebesar 0,539 , artinya hubungan antara orientasi kewirausahaan, orintasi pasar, dan moderasi dengan 
kinerja usaha dikategorikan cukup kuat (sedang).

Berdasarkan nilai $\mathrm{R}$ yang dihasilkan ketiga model regresi diketahui bahwa model 1 (uji regresi sederhana) menghasilkan nilai $\mathrm{R}$ sebesar 0,346; model 2 (uji selisih mutlak 1) menghasilkan nilai $\mathrm{R}$ sebesar 0,569; model 3 (uji selisih mutlak 2) menghasilkan nilai $R$ sebesar 0,539;. Dengan demikian moderasi kreativitas memberikan peningkatan nilai $\mathrm{R}$ sebesar 0,223 atau sekitar 22,3\% sedangkan moderasi orientasi pasar memberikan peningkatan nilai $\mathrm{R}$ sebesar 0,193 atau sekitar 19,3\%

Kesimpulannya bahwa kreativitas dan orientasi pasar adalah variabel moderating yang dapat memperkuat pengaruh orientasi kewirausahaan terhadap kinerja usaha pada pengusaha fesyen di BTC dan PGS Surakarta. Untuk mengoptimalkan kinerja usaha, moderasi kreativitas memberikan kontribusi yang lebih besar dibandingkan orientasi pasar. Namun kedua variabel moderasi ini penting untuk dikembangkan sebagai upaya dalam mengoptimalkan kinerja usaha para pengusaha fesyen di BTC dan PGS Surakarta.

\section{Pembahasan}

Hasil pengujian hipotesis 1 menunjukkan bahwa orientasi kewirausahaan berpengaruh signifikan terhadap kinerja usaha, berarti peningkatan orientasi kewirausahaan berpengaruh terhadap peningkatan kinerja usaha pada pengusaha fesyen di BTC dan PGS Surakarta. Implikasi dari temuan ini orientasi kewirausahaan yang dinilai dari keinovasian, keproaktifan, dan keberanian berisiko dalam menjalankan perusahaan akan membantu perusahaan dalam menciptakan nilai bagi pelanggan, serta meningkatkan kemampuan menghadapi pesaing maupun risiko pasar sehingga orientasi kewirausahaan yang tinggi dapat digunakan sebagai langkah-langkah strategis dalam memenangkan persaingan bisnis. Temuan ini konsisten dengan konsep orientasi kewirausahaan dari Miller (1983) serta Covin \& Slevin (1989) bahwa orientasi kewirausahaan yang terkait dengan perilaku inovatif, perilaku proaktif dan keberanian mengambil risiko mampu meningkatkan kinerja usaha. Konsep orientasi kewirausahaan juga dikemukakan oleh Miller (1983) serta Lamkin \& Des (2001) bahwa orientasi kewirausahaan sebagai entrepreneurial perusahaan berkaitan dengan inovasi produk, melakukan kegiatan yang beresiko, inovasi yang proaktif serta agresif dalam menghadapi pesaing yang diindikatorkan dengan keinovatifan, keproaktipan, keagresipan bersaing dan berani mengambil risiko. Temuan hasil penelitian ini mendukung penelitian yang pernah dilakukan oleh Rita Indah Mustikowati \& Irma Tysari (2014) 
bahwa orientasi kewirausahaan berpengaruh positif dan signifikan terhadap kinerja perusahaan pada UKM Sentra Kabupaten Malang. Temuan penelitian ini juga mendukung penelitian yang dilakukan oleh Dewi Kusuma Rahman dkk (2015) pada pengusaha UKM kerajinan bambu di desa Gintangan Kabupaten Banyuwangi bahwa dimensi-dimensi orientasi kewirausahaan terdiri dari kreativitas dan perilaku inovatif berpengaruh signifikan terhadap keberhasilan usaha melalui motivasi usaha. Temuan penelitian ini tidak sejalan dengan penelitian yang dilakukan oleh Cynthia Vanessa Djodjobo \& Hendra N. Tawas (2014) bahwa orientasi kewirausahaan tidak berpengaruh signifikan terhadap keunggulan bersaing pada usaha nasi kuning di kota Manado.

Hasil pengujian hipotesis 2 menunjukkan bahwa kreativitas memoderasi pengaruh orientasi kewirausahaan terhadap kinerja usaha, berarti kreativitas yang tinggi akan memperkuat pengaruh orientasi kewirausahaan terhadap kinerja pada pengusaha fesyen di BTC dan PGS Surakarta. Temuan ini sejalan dengan pendapat Gaspersz (dalam Louis Utama dan Jeremy Kristanto Nadi, 2017) yang menyatakan, kreativitas pengusaha amat penting dikembangkan yaitu selalu berupaya memikirkan ide-ide baru dan berguna atas usaha yang dikelolanya. Untuk menjadi wirausaha yang kreatif perlu mengembangkan tiga kemampuan yaitu berkaitan dengan kemampuan mengkombinasi, kemampuan memecahkan masalah, kemampuan secara operasional yang kreatif. Dengan demikian wirausaha yang kreatif apabila mampu mengembangkan ide-ide baru serta menemukan cara-cara baru dalam memecahkan persoalan untuk menghadapi peluang bisnis. Menurut Pretorius, et al. (2005) dan Ernani Hadiyati (2011) kreativitas pengusaha dapat dilakukan dengan mengembangkan otonomi, memikirkan imajinasi, gigih, percaya diri, tidak takut gagal, memperhitungkan resiko, serta mampu mengasah ide-ide baru. Implikasi dari temuan ini, bahwa semakin tinggi interaksi orientasi kewirausahaan dengan kreativitas, maka kinerja usaha akan semakin tinggi. Sejalan dengan ketatnya persaingan bisnis fesyen, kreativitas pengusaha fesyen amat penting dimiliki. Hal ini dapat dilakukan dengan mengembangkan ide-ide baru untuk menciptakan kreasi kekinian pada produk fesyen, mencari informasi fesyen up to date yang dapat meningkatkan daya saing produk, serta berusahya mencari solusi terbaik dalam menghadapi peluang bisnis fesyen. Dengan demikian, semakin tinggi kreativitas maka pengusaha fesyen akan semakin mampu mengembangan ideide baru dan memecahkan persoalan untuk menghadapi peluang bisnis. 
Ide-ide kreatif dan cara-cara baru yang dikembangkan akan memberikan kontribusi pada peningkatan daya saing sehingga orientasi kewirausahaan akan semakin berkembang dan selanjutnya akan meningkatkan kinerja usaha.

Hasil pengujian hipotesis 3 menunjukkan bahwa orientasi pasar memoderasi pengaruh orientasi kewirausahaan terhadap kinerja usaha, berarti orientasi pasar yang tinggi akan memperkuat pengaruh orientasi kewirausahaan terhadap kinerja pada pengusaha fesyen di BTC dan PGS Surakarta. Implikasi dari temuan ini, bahwa semakin tinggi interaksi orientasi kewirausahaan dengan orientasi pasar, maka kinerja usaha akan semakin tinggi. Orientasi pasar dalam penelitian ini merupakan perilaku untuk memberikan nilai superior kepada pelanggan, respon terhadap tindakan pesaing dan melakukan komunikasi secara internal. Berdasarkan hasil temuan ini, orientasi pasar yang dinilai dari orientasi pelangan, orientasi pesaing dan koordinasi antar fungsi amat penting untuk dikembangkan terutama dalam menghadapi ketatnya persaingan bisnis. Narver \& Salter (1990) menyatakan bahwa orientasi pasar dapat menciptakan kinerja superior dalam jangka panjang. Dalam praktiknya kinerja perusahaan superior dicerminkan dengan usaha perusahaan memahami kebutuhan pelanggan, menekankan kepuasan pelanggan, mengukur kepuasan pelanggan, memberikan perhatian pada layanan purna jual, dan merespon secara cepat tindakan pesaing.

Orientasi pasar merupakan perilaku untuk memberikan nilai superior kepada pelanggan, respon terhadap tindakan pesaing dan melakukan komunikasi secara internal (Venkatesan \& Soutar, 2000; Farrell \& Oczkowski; 2002). Penelitian Guenzi \& Troilo (2006) menemukan bahwa kemampuan untuk menciptakan nilai superior bagi konsumen mengalir dari kapabilitas pemasaran yang dimiliki perusahaan. Lee \& Hsieh (2010) menyatakan bahwa dalam tingkat persaingan yang tinggi, perusahaan perlu memiliki keunggulan bersaing dalam pasar global. Penelitian yang dilakukan oleh Perengki Susanto (2012) menunjukkan bahwa orientasi pasar berpengaruh signifikan terhadap kinerja perusahaan kecil di Daerah Istimewa Yogyakarta.

\section{KESIMPULAN}

Berdasarkan hasil pengujian setiap hipotesis, diperoleh kesimpulan (1) Orientasi kewirausahaan berpengaruh signifikan terhadap kinerja usaha pada pengusaha fesyen di BTC dan PGS Surakarta. (2) Kreativitas memoderasi pengaruh orientasi kewirausahaan terhadap kinerja usaha pada pada pengusaha fesyen di BTC dan PGS Surakarta. (3) Orientasi pasar memoderasi 
pengaruh orientasi kewirausahaan terhadap kinerja usaha pada pada pengusaha fesyen di BTC dan PGS Surakarta. Implikasi dari temuan ini, pengusaha fesyen di BTC dan PGS Surakarta sebaiknya tidak cukup hanya memiliki orientasi kewirausahaan, melainkan harus didukung dengan kreativitas dan orientasi pasar yang semakin tinggi sehingga kinerja usaha akan semakin optimal.

Pengusaha fesyen di BTC dan PGS Surakarta disarankan untuk terus menciptakan daya saing dengan memberikan nilai tambah atas produk/jasa agar dapat memenuhi tuntutan dan harapan konsumen. Hal ini dapat dilakukan dengan meningkatkan kreativitas pada material dan desain fesyen yang up to date, memahami kekuatan dan kelemahan pesaing, serta meningkatkan kualitas pelayanan online. Penelitian mengenai faktorfaktor yang mempengaruhi kinerja usaha fesyen masih perlu dilakukan. Penelitian selanjutnya diharapkan mengembangkan model dengan memasukkan variabel pemediasi atau mengkaji faktor-faktor anteseden lain misalnya pembelajaran organisasi dan karakteristik manajer.

\section{DAFTAR PUSTAKA}

Cynthia Vanessa Djodjobo dan Hendra N. Tawas, 2014, "Pengaruh Orientasi Kewirausahaan, Inovasi Produk, dan Keunggulan Bersaing terhadap Kinerja Pemasaran Usaha Nasi Kuning di Kota Manado", Jurnal EMBA, Vol. 2 (3), November. Hal. 1214-1224.

Dwi Wahyu Pril Ranto. 2016. "Pengaruh Orientasi Kewirausahaan Terhadap Kinerja UMKM Bidang Kuliner Di Yogyakarta". JBMA. Vol. 3 (2). Hal. 1-11.

Ernani Hadiyati. 2011. "Kreativitas dan Inovasi Berpengaruh Terhadap Kewirausahaan Usaha Kecil". Jurnal Manajemen dan Kewirausahaan. Vol. 13 (1). Hal. 8-16.

Gosselin, Maurice. 2005. “An Empirical Study of Performance Measurement in Manufacturing Firm". International Journal of Productivity and Performance Management. Vol. 54 No.5/6. pp.419-437.

Halim, Djumilah Hadiwidjojo, Solimun, dan Djumahir, 2012.

"Kapabilitas Pemasaran sebagai Mediasi Pengaruh Orientasi Pasar Orientasi Pembelajaran dan Orientasi Kewirausahaan terhadap Kinerja Pemasaran (Studi pada Usaha Menengah di Sulawesi Tenggara)". Jurnal Aplikasi Manajemen. Vol. $10 \quad$ (3). September. Hal. 472-484.

Heny Welsa. 2009. "Pengaruh Kewirausahaan terhadap Kemampuan Usaha serta Kinerja Usaha Rumah Makan Padang di Daerah Istimewa Yogyakarta". EKUITAS. Vol. 13 (3); Hal. 371-387.

Imam Ghozali, 2011, Aplikasi Analisis Multivariate dengan progam SPSS. Badan penerbit Universitas Dipenogoro. Semarang. 
Liao. Debbie and Philip Sohmen. 2001. "The Development of Modern Entreprenuership in China". Stanford Journal of East Asia Affair. Vol 1.

Louis Utama dan Jeremy Kristanto Nadi. 2017. "Pengaruh Kreativitas terhadap Kinerja Usaha dengan Orientasi Kewirausahaan sebagai Mediasi pada Wirausaha di ITC Cempaka Mas". Conference on Management and Behavioral Studies. Universitas Tarumanagara Jakarta. 12 Oktober 2017. Hal. 80-88.

Mulato Santosa dan Muhammad Nasir. 2014. "Orientasi Kewirausahaan dan Kinerja Perusahaan pada Kondisi Persaingan Dinamis: Pemediasian Pembelajaran Organisasional". $3^{\text {rd }}$ Economics \& Business Research Festival. Fakultas Ekonomi UKSW. 13 November 2014. Hal. 564-577.

Perengki Susanto. 2012. "Pengaruh Orientasi Pasar pada Kinerja Perusahaan Kecil". Jurnal Kajian Manajemen Bisnis. Vol 1 (2). Hal. 45-60.

Pretorius, M., Millard, S. M., \& Kruger, M. E. 2005. "Creativity, innovation and implementation: Management experience, venture size, life cycle stage, race and gender as moderators". South African Journal of Business Management, Vol. 36 (4), pp. 55-68.

Rita Indah Mustikowati dan Irma Tysari. 2014. "Orientasi Kewirausahaan. Inovasi. dan Strategi Bisnis untuk Meningkatkan Kinerja Perusahaan (Studi pada UKM Sentra Kabupaten Malang)".
Jurnal: MODERNISASI. Vol. 10 (1). Februari. Hal. 23-37.

Weinzimmer, L.G. 2011. "Creativity and firm level performance, the mediating effects on action orientation". Journal of Management Issues. Vol. 23(1). pp 62-82. 